\title{
Financial Market Performance Affected by the Covid- 19 Case: Study on Indonesian Composite Stock Index
}

\author{
I Gd Nandra Hary Wiguna ${ }^{1, *}$ Nyoman Ayu Wulan Trisna Dewi ${ }^{1}$ I Nyoman Putra \\ Yasa $^{1}$
}

${ }^{1}$ Department of Economics and Accounting, Universitas Pendidikan Ganesha, Singaraja, Indonesia
${ }^{*}$ Corresponding author. Email: $\underline{\text { hary.wiguna@ undiksha.ac.id }}$

\begin{abstract}
By evaluating Indonesia's composite stock index during the Covid-19 pandemic, this paper aims to assess the capital market's performance in Indonesia (IHSG). To begin with, the first study was undertaken by comparing the composite stock index before and after the announcement of the first case of Covid-19 in Indonesia. Afterwards, a research was carried out on how the Covid-19 case had an impact on the composite stock index's performance. After conducting testing, it has been determined that the stock index has changed significantly after the Covid-19 case was made public. It is also recognized that the Covid-19 case has a detrimental impact on the Indonesian stock market's stock index. It is predicted that the findings of this study would be used in the future by investors and potential investors as a factor when making investment decisions in times of extreme volatility. As a result, the company will be able to avoid losses and maximize stock return.
\end{abstract}

Keywords: Capital market performance, Covid-19, Composite stock index.

\section{INTRODUCTION}

The WHO declared Covid-19 an international pandemic in March 2020. Covid-19 first appeared in Wuhan, China, in late December 2019 [1]. In order to stop the spread of Covid-19, the Chinese authorities had to clamp down. 80,000 cases and 3,000 deaths in less than two months. Covivirus 19 (Covid) afflicts countries in Asia, America, Europe, As a result, Covid-19 spread to many countries. As of May 8, 2020, the pandemic has spread to the US, Spain, Italy, England, Russia, France, Germany, Brazil, Turkey, and Iran. Six countries outnumber China in terms of deaths: the US, Italy, Spain, France, Britain, Germany, Iran, and Belgium. Meanwhile, the Netherlands and Canada are approaching China in terms of victims [2].

It continued to rise in Indonesia from March 2020 to January 2021. An economic impact has been felt in Indonesia as quickly as the Covid-19 outbreak spread. Public, government, and business sectors have expressed their displeasure with the Covid-19 outbreak. Social distancing, online learning for education, work from home for formal sector workers, delays and cancellations of various government and private activities, the termination of some public transportation and the implementation of Scaled Social Restrictions are some of the preventative measures taken by both the community and the government. Large (PSBB), restrictions on community activities (PKM) in many Indonesian locations, slowing economic turnover [3]. The World Bank and the IMF forecast a global economic crisis because to the Covid-19 pandemic. Some experts equate it to or worse than the Great Depression of 1920-1930. (BBC, April 16, 2020). Economic prospects are grim, say Bank Indonesia and the Indonesian Finance Minister. Until early 2021. The economy is anticipated to contract in 2020 [4].

Concerns due to Covid-19 also hit global financial markets, which indicates that during the period of the spread of COVID-19, financial markets experienced high uncertainty [3]. According to [5], The financial markets and global economy have been rocked by the discovery of the Covid-19 disease. There has been evidence of the pandemic's impact on global stock markets almost everywhere. The Indonesian capital market is also under pressure amid efforts to fight the coronavirus (Covid-19) pandemic. JCI on trading March 30, 2020 closed down 2.88 percent at the level of $4,414.5$. The Indonesia Stock 
Exchange (IDX) froze or halted trade again since the index plunged 5\% to 4,318.29. Previously, the IHSG gained 4.76 percent and finished at 4,545.57 [6].

The Covid-19 pandemic impacted the capital market, according to [5] who performed study in Pakistan. [7] reported that 30 firms' share prices fell before and after the revelation of the first Covid-19 case in Indonesia, while 15 companies' share prices rose. Meanwhile, the Covid-19 epidemic and the country's social distancing policies (WFH and PSBB) influenced capital market dynamics (indicated from the movement of the IHSG index on the IDX) [2]. The number of Covid-19 instances in Indonesia also influences the IHSG Composite Stock Price Index [3].

The Covid-19 pandemic in Indonesia necessitates an examination into the possible financial market implications. Before and after the Covid-19 window occurrence, we'll evaluate the Indonesian stock market's reaction to these events. Analyzing whether or not the confirmed positive Covid-19 case statistics have an impact on the composite stock index (CSPI).

\section{LITERATURE REVIEW \& HYPOTHESIS DEVELOPMENT}

\subsection{Signaling Theory}

The information that has been realized will be able to cause a positive or negative reaction to the company's stock price. when information is published and received by all market participants, of course, must analyze and interpret the information whether it is a positive signal or a negative signal. The signals received by investors will certainly have an influence on the volume of stock trading. If investors receive a positive signal, it will result in an increase in demand for shares, resulting in an increase in stock prices. On the other hand, if a negative signal is received by investors on the information realized by the company, it will cause the demand for shares to decrease, so that the share price also decreases [8].

\subsection{Capital market}

The capital markets can trade a wide range of longterm financial instruments, such as debt securities (bonds), equity securities (stocks), mutual funds, derivative instruments, and so on.. For enterprises and other organizations (including the government), the capital market serves as a source of finance and a location where investors can conduct business. According to a study from the Indonesian Stock Exchange (ISE) in 2018, the capital market provides a wide range of facilities for trading and other associated operations.

The 1995 Indonesian Capital Market Law defines it as "activities linked to the public offering and trading of securities, public companies relating to the securities they issue, institutions and professions associated to securities". First, the capital market allows firms to raise funds from investors, and second, it allows them to raise funds from the general public. The general people can invest in capital markets and financial instruments such as stocks, bonds, mutual funds, etc. for business development and expansion. Thus, according to the 2019 Indonesia Stock Exchange report, investors can allocate funds based on the rewards and dangers of each instrument.

\subsection{Stocks and Stock Indices}

Investing in a company's stock is an investment in a portion of the company's equity. This provides the shareholder with proportional rights to the corporation's assets and profits equal to the number of shares held [2]. The IDX, on the other hand, defines shares as a symbol of ownership in a corporation or limited liability firm. Stocks, on the other hand, are a popular choice for investors because of their ability to generate attractive returns. Stock indexes are statistical indicators of a collection of equities' total price movement. They are evaluated regularly and based on certain criteria and methodologies. The composite stock index used in this study is the IHSG on the IDX.

\subsection{The Effect of Covid-19 Cases on the Capital Market}

According to [5], the Covid-19 epidemic has had an impact on Pakistan's stock market. [7] claimed that 30 firms' share prices declined before and after the first Covid-19 case was revealed in Indonesia, while 15 firms' share prices soared. According to [2], the Covid-19 outbreak and the country's social distancing policies (WFH and PSBB) altered capital market dynamics (indicated from the movement of the IHSG index on the IDX). In Indonesia, the number of Covid-19 occurrences has a direct impact on the IHSG Composite Stock Price Index [3].

Thus, the hypotheses that can be proposed in this study are as follows:

$\mathrm{H}_{1}$ : Covid-19's announcement has had a significant impact on the IHSG composite stock index (IHSG).

$\mathrm{H}_{2}$ : The Indonesian capital market is affected by the Covid-19 case. 


\section{METHOD}

\subsection{Research Method}

This research employs descriptive quantitative event studies. An event study looks at how an event affects a set of dependent variables [9]. The dependent variable is the Indonesian Stock Exchange index. The index is the independent variable. Secondary data include Covid-19 case data and 2020 BEI composite stock index history. This is calculated by comparing the composite stock index before and after the event period (Fig. 1). The estimating period is 31 days before and after the occurrence. The tournament will end on March 2, 2020. Then we'll compare Covid-19 to the composite stock index. The research framework is as follows (Fig. 2).

\subsection{Data Analysis}

\subsubsection{Descriptive statistics}

Descriptive statistics is a data analysis technique by organizing, summarizing, and presenting data into a more informative form [10]

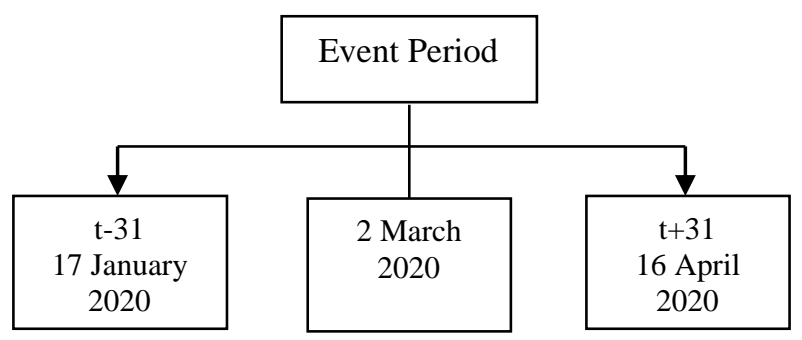

Figure 1 Research Estimation Period (Hypothesis 1)

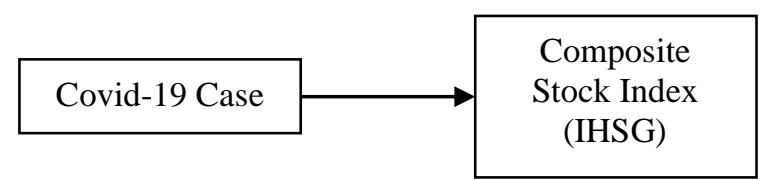

Figure 2 The Effect of Covid-19 Cases on the Capital Market (Hypothesis 2)

This descriptive data shows the uniformity of the data used in the study.

\subsubsection{Classic Assumption Test}

The classical assumption test is carried out to see whether the data used in the study has met the assumptions needed to produce accurate research. The classical assumption tests included normality, multicollinearity, heteroscedasticity, and autocorrelation.

\subsubsection{Hypothesis test}

Hypothesis testing is done to determine whether the previously formed hypothesis is consistent with the findings of the investigation. The hypothesis tests that were performed are as follows:

t-Test with Paired Samples. The t-test was used to determine the magnitude of the difference in the composite stock index in Indonesia before and after the announcement of the Covid-19 case. This test was carried out to put the first hypothesis to the test.

Linear Regression. This experiment was carried out to examine the impact of the Covid-19 case on the performance of the Indonesian capital market. The IHSG index is used to illustrate capital market performance. With a significance level of 5\%, how much influence does the independent variable have on the dependent variable? Significant variables are those with p-values smaller than the significance level. The regression model of this study is:

IHSG $=\beta_{0}+\beta_{1}$ COVID $-19+\varepsilon$

\section{RESULTS \& DISCUSSION}

\subsection{Statictic Descriptive}

According to the descriptive statistical test results in Table 1, the Composite Stock Price Index (IHSG) before the release of the first case of Covid-19 had an average of Rp. 5,965.37, and the average after the first case was announced was Rp. 4,698.37. The data collected include 31 data points before and 31 data points following the announcement of the first incidence of covid-19.

\subsection{Paired Sample t-Test}

The paired sample t-test has a significant value of 0.000 , as shown in Table 2. This value is less than 0.005 (P Value 0.05). This number depicts the composite stock index before and after the revelation of the first case of Covid-19 in Indonesia. As a result, it is possible to conclude that the first hypothesis in this study is acceptable. Following that, the regression model will be assessed using the classical assumption test to determine whether there is a link between the Covid-19 case and stock performance on the IDX.

\subsection{Classic assumption test}

\subsubsection{Normality test}

The standard assumption test was performed to ensure the model's practicality in testing the influence of the Covid-19 scenario on the composite stock index (IHSG). The Kolmogorov-Smirnov test was used to calculate the Asymp value. Sig. (2-tailed) $=0.200$, which 
is greater than 0.05 . This signifies that the data utilized in this study was distributed in a standardized fashion (Table 3).

\subsubsection{Multicollinearity Test}

Table 4 shows the results of the regression model's multicollinearity test, which shows that all variables have tolerance values more than 0.1 and VIFs less than 10. It is possible to conclude in the absence of multicollinearity. In a decent regression model, the independent variables should not be connected to each other. The variables are not orthogonal if the independent variables are connected.

If a regression model has a VIF value less than 10 and a tolerance number more than 0.10 , it is said to be free of multicollinearity symptoms. Table 4 presents the results of the regression model's multicollinearity test, which reveals that all variables in this study have a tolerance value greater than 0.1 and a VIF less than 10. It is possible to conclude that there is no multicollinearity.

Table 1. Descriptive Statistics (IHSG)

\begin{tabular}{|l|l|l|l|l|l|}
\hline \multicolumn{7}{|c|}{ Descriptive Statistics } \\
\hline \multicolumn{2}{|c|}{} & Mean & N & Std. Deviation & Std. Error Mean \\
\hline Pair 1 & IHSG_t-31 & 5965.3713 & 31 & 201.21594 & 36.13945 \\
\cline { 2 - 7 } & IHSG_t+31 & 4698.3661 & 31 & 467.35123 & 83.93876 \\
\hline
\end{tabular}

Source: Processed Data, 2021

Table 2. Paired Sample t-Test

\begin{tabular}{|l|r|}
\hline \multicolumn{2}{|c|}{ Paired Sample t-Test } \\
\hline Mean & 1267.00516 \\
\hline Std. Deviation & 389.76141 \\
\hline Std. Error Mean & 70.00322 \\
\hline Lower & 1124.03952 \\
\hline Upper & 1409.97080 \\
\hline $\mathrm{t}$ & 18.099 \\
\hline $\mathrm{df}$ & 30 \\
\hline Sig. (2-tailed) & .000 \\
\hline
\end{tabular}

Source: Processed Data, 2021

Table 3. Normality test

\begin{tabular}{|c|c|c|c|}
\hline \multicolumn{3}{|c|}{ One-Sample Kolmogorov-Smirnov Test } \\
\hline \multicolumn{2}{|c|}{$\mathrm{N}$} & Covid-19 & IHSG \\
\hline \multirow{2}{|c|}{ Normal Parameters ${ }^{\mathrm{a}, \mathrm{b}}$} & Mean & 24.6775 & 30 \\
\cline { 2 - 4 } & Std. Deviation & 19.96609 & 3.54277 \\
\hline \multirow{2}{*}{ Most Extreme Differences } & Absolute & .127 & .117 \\
\cline { 2 - 4 } & Positive & .127 & .117 \\
\cline { 2 - 4 } & Negative & -.122 & -.074 \\
\hline Test Statistic & & .127 & .117 \\
\hline Asymp. Sig. (2-tailed) & .200 & .200 \\
\hline
\end{tabular}

Source: Processed Data, 2021 
Table 4. Multicollinearity Test

\begin{tabular}{|l|c|c|c|}
\hline \multicolumn{3}{|c|}{ Coefficients $^{\text {a }}$} \\
\hline \multicolumn{2}{|c|}{ Model } & \multicolumn{2}{|c|}{ Collinearity Statistics } \\
\cline { 3 - 4 } & Tolerance & VIF \\
\hline 1 & Covid-19 & 1.000 & 1.000 \\
\hline a. Dependent Variable: IHSG & & \\
\hline
\end{tabular}

Source: Processed Data, 2021

Table 5. Heteroscedasticity Test

\begin{tabular}{|c|c|c|c|c|c|c|}
\hline \multicolumn{7}{|c|}{ Coefficients $^{a}$} \\
\hline & \multirow[b]{2}{*}{ Model } & \multicolumn{2}{|c|}{ Unstandardized Coefficients } & \multirow{2}{*}{$\begin{array}{c}\begin{array}{c}\text { Standardized } \\
\text { Coefficients }\end{array} \\
\text { Beta }\end{array}$} & \multirow[b]{2}{*}{$\mathrm{t}$} & \multirow[b]{2}{*}{ Sig. } \\
\hline & & B & Std. Error & & & \\
\hline \multirow[t]{2}{*}{1} & (Constant) & 2.921 & .509 & & 5.741 & .000 \\
\hline & Covid-19 & -.016 & .016 & -.181 & -.976 & .338 \\
\hline
\end{tabular}

Source: Processed Data, 2021

Table 6. Autocorrelation Test

\begin{tabular}{|c|c|c|c|c|c|}
\hline \multicolumn{6}{|c|}{ Model Summaryb } \\
\hline Model & $\mathrm{R}$ & R Square & $\begin{array}{l}\text { Adjusted R } \\
\text { Square }\end{array}$ & $\begin{array}{c}\text { Std. Error of the } \\
\text { Estimate }\end{array}$ & Durbin-Watson \\
\hline 1 & $.333^{a}$ & .111 & .079 & 3.40031 & 1.844 \\
\hline \multicolumn{6}{|c|}{ a. Predictors: (Constant), Covid-19 } \\
\hline \multicolumn{6}{|c|}{ b. Dependent Variable: IHSG } \\
\hline
\end{tabular}

Source: Processed Data, 2021

Table 7. Linear Regression Test

\begin{tabular}{|c|c|c|c|c|c|}
\hline \multicolumn{6}{|c|}{ Coefficientsa } \\
\hline \multirow[b]{2}{*}{ Model } & \multicolumn{2}{|c|}{ Unstandardized Coefficients } & \multirow{2}{*}{$\begin{array}{l}\begin{array}{l}\text { Standardiz } \\
\quad \text { ed }\end{array} \\
\text { Coefficients } \\
\text { Beta }\end{array}$} & \multirow[b]{2}{*}{$\mathrm{t}$} & \multirow[b]{2}{*}{ Sig } \\
\hline & B & Std. Error & & & \\
\hline (Constant) & 210.934 & 64.147 & & 3.288 & .003 \\
\hline IHSG & -2.714 & .933 & -.482 & -2.907 & .007 \\
\hline \multicolumn{6}{|c|}{ a. Dependent Variable: Covid-19 } \\
\hline
\end{tabular}

Source: Processed Data, 2021

\subsubsection{Heteroscedasticity Test}

Table 5 of the Glejser test shows that the research model is devoid of heteroscedasticity, with all independent variables having significance values greater than 0.05 . 


\subsubsection{Autocorrelation Test}

The results of the autocorrelation test showed that the Durbin-Watson (d) value was 1.844 and the du value was 1.489. With the criteria du $<\mathrm{d}<4$-du then, $1,489<$ $1,844<2,511$. So, it can be concluded that there are no symptoms of autocorrelation (Table 6).

\subsection{Effect of Covid-19 Cases on Capital Market Performance}

The significance value for the linear regression test is 0.007 (Table 7). This score is more than 0.05 , indicating the Covid-19 case having an impact on the Indonesian stock market. It is also known that $\mathrm{t}-2,907$. This reveals a negative association between the two variables. If Covid-19 cases rise, the Indonesian stock market will suffer. So, the study's second hypothesis is accepted.

\subsection{Discussion}

The IHSG's performance on the Indonesian capital market before and after the first Covid-19 case was announced was shown to be significantly different. The results support other previous studies. the data before and during the pandemic showed that PT Ramayana Lestari Sentosa's shares and sales volume differ significantly, according to study by [11]. Following the announcement of the first Covid-19 case in Indonesia, [12] said that the price of sharia shares fell and the trading volume increased.

This condition was caused by investors who sold their shares due to the psychological anxiety reaction of investors to stock returns caused by the impact of the Covid-19 pandemic. Asian capital markets affected by the pandemic experienced abnormally negative returns compared to other countries. There is information that is effective in increasing investors' pessimistic sentiment towards returns and worries about uncertainty [13].

The results of the second hypothesis testing demonstrate that the Covid-19 case had an impact on the performance of the Indonesian capital market's composite stock index. This result is inline with the studies from [5], [7], [2], and [3]. The studies confirmed that the pandemic, in various countries, fully and partially impacted the share price, financial performance, and IHSG.

The pandemic has promt investor to sell their stock holdings [14]. Pandemic conditions also had an impact on the stock market [15], [2], [13], caused global stock markets to fall [16], and increased inefficiency in stock market [17]. Additionally, this has a negative impact on Indonesia's capital market, which has an effect on investors' ability to make investment decisions [18]. In short, Covid 19 negatively impacts corporate returns [19].

Before the outbreak of the Covid-19 pandemic, Indonesia's stock market was considered relatively stable. Before 2020, the IHSG composite stock index is expected to remain stable (May 2019-December 2019). When the IHSG's value decreased in January 2020 [20]. The outbreak of Covid-19 in Wuhan, China, began at that time. Later, the disease had a negative impact on other countries such as Indonesia. Covid-19 began taking positive victims in Indonesia in February and March 2020, resulting in a significant drop in the value of the IHSG. The Indonesian government began enforcing a work-from-home policy for its residents towards the end of March 2020 [21].

The policies that have been taken by the government ultimately have an impact on the industry. Many companies are furloughing or laying off even laying off employees. This is because the company's operational activities must be drastically reduced. To put it another way, this condition causes the company to reduce or stop production, which ultimately affects sales. Additionally, if demand from customers drops, companies may reduce their output as well. This will have a detrimental influence on the company's finances and general performance in the long run. According to the Financial Services Authority [22], 58.73 percent of the 475 issuers that submitted financial reports in the first quarter of 2020 reported a fall in profits. A drop in the company's performance might cause the stock price to fall on the stock exchange. Companies, on the other hand, reduce the number of employees, which increases the number of unemployed and has an impact on macroeconomic conditions.

Overall, stock values in all industrial sectors fell, and this led to a significant correction of the IHSG value. Some issuers have even begun to prepare funds for stock buybacks. Uncertain conditions have also caused some foreign investors to sell shares that have been invested in Indonesia. This is due to investor concerns about the declining economic conditions in Indonesia. In Indonesia, all industrial sectors experienced a decline [21].

\section{CONCLUSION}

This study attempts to compare the IHSG composite stock price index and the Covid-19 case on the performance of Indonesian capital market shares. This analysis found significant variations in stock prices before and after the first Covid-19 case was announced. 
The Covid-19 case also had an impact on the Indonesian stock market.

These two findings can make a very useful contribution to investors and potential investors on the Indonesia Stock Exchange. Conditions like this can be a valuable lesson as well as the results of this research can be an illustration to help investors and potential investors make decisions before investing in future activities. Similar events or other events may occur in the future, based on experience and research results like this, investors can avoid losses and hopefully can be a strategy to maximize stock returns in any condition.

This research is still far from perfect and still needs to be developed further for the next research. This research only focuses on event studies that have occurred in Indonesia, further research is expected to develop research by also paying attention to other factors that may affect stock performance in the capital market. Event studies in the capital market can be combined with other factors such as exchange rates, interest rates, and socio-political conditions when an event occurs.

\section{REFERENCES}

[1] J. Hopkins, "COVID-19 Dashboard by the Center for Systems Science and Engineering (CSSE) at Johns Hopkins University (JHU)," John Hopkins University of Medicine, 2020.

[2] D. Junaedi and F. Salistia, "Dampak Pandemi Covid19 terhadap Pasar Modal di Indonesia: Studi Kasus Indeks Saham Komposit (IHSG)," J. Ekon. Keuang. Bisnis Syariah Al-Kharaj, vol. 2, no. 2, pp. 109-131, 2020.

[3] N. N. Halisa, "Pengaruh Covid-19, Nilai Tukar Rupiah dan Indeks Harga Saham Gabungan Asing Terhadap Indeks Harga Saham Gabungan Indonesia (IHSG)," J. Manaj. dan Organ., vol. 11, no. 3, pp. 170-178, 2020.

[4] S. Mulyani, "Pemerintah Waspada Dampak Pandemi Covid-19 Terhadap Ekonomi Indonesia. Siaran pers Kenenterian Keuangan RI pada 17 April 2020.”.

[5] S. Ahmed, "Impact of COVID-19 on Performance of Pakistan Stock Exchange," 2020. .

[6] M. Wenno, "Dampak Covid-19 Terhadap Perubahan Harga Saham Dan Volume Transaksi (Studi Kasus Pada Pt. Bank Mandiri.Tbk)," J. SOSOQ, vol. 8, no. 2, 2020.

[7] G. A. Febriyanti, "Dampak pandemi Covid-19 terhadap harga saham dan aktivitas volume perdagangan (Studi kasus saham LQ-45 di Bursa Efek Indonesia)," Indones. Account. J., vol. 2, no. 2, 2020.

[8] I. K. Suryawana, "Pengaruh Earnings Per Share Terhadap Harga Saham Dengan Dividend Per Share
Sebagai Variabel Moderasi," E-Jurnal Akunt., vol. 3, no. 2, pp. 212-228, 2013.

[9] W. S. Woon, Introduction to the Event Study Methodology. singapore: Singapore Management University, 2004.

[10]D. A. Lind, W. G. Marchal, and S. A. Wathen, Statistical Techniques in Business \& Economics 14/E. Jakarta: Salemba Empat, 2010.

[11]I. Nurmasari, "Dampak Covid-19 Terhadap Perubahan Harga Saham dan Volume Transaksi (Studi Kasus Pada PT. Ramayana Lestari Sentosa, Tbk.)," J. Sekuritas (Saham, Ekon. Keuang. dan Investasi), vol. 3, no. 3, pp. 230-236, 2020.

[12] Saputro, "Analisis Harga Saham Syariah dan Volume Perdagangannya Sebelum dan Sesudah Pengumuman Covid 19," Ekon. dan Educ. J., vol. 2, no. $2,2020$.

[13]H. Liu, A. Manzoor, C. Wang, L. Zhang, and Z. Manzoor, "The COVID-19 outbreak and affected countries stock markets response," Int. J. Environ. Res. Public Health, vol. 17, pp. 1-19, 2020.

[14]D. L. Kusnandar and V. I. Bintari, "Perbandingan Abnormal Return SahamSebelum dan Sesudah Perubahan Waktu Perdagangan Selama Pandemi Covid-19," J. Pasar Modal dan Bisnis, vol. 2, no. 2, pp. 195-202, 2020

[15]H. Qing, L. Junyi, W. Sizhu, and Y. Jishuang, "The impact of COVID-19 on stock markets," Econ. Polit. Stud., vol. 8, no. 3, pp. 275-288, 2020, doi: 10.1080/20954816.2020.1757570.

[16]C. N. Collins, "Effect of COVID-19 Pandemic on Global Stock Market Values: A Differential Analysis," Acta Univ. Danubius, no. 16, pp. 255269, 2020.

[17] V. Lalwani and V. V Meshram, "Stock Market Efficiency in the Time of COVID-19: Evidence from Industry Stock Returns," Int. J. Account. Financ. Rev., vol. 5, no. 2, pp. 40-44, 2020, doi: 10.46281/ijafr.v5i2.744.

[18] A. U. Al Umar, H. Pitaloka, E. Hartati, and D. Fitria, "The Economic Impact of the Covid-19 Outbreak: Evidence from Indonesia," J. Inov. Ekon., 2020, doi: 10.22219/jiko.v5i3.11889.

[19] A. M. Al-Awadhi, K. Alsaifi, A. Al-Awadhi, and S. Alhammadi, "Death and contagious infectious diseases: Impact of the COVID-19 virus on stock market returns," J. Behav. Exp. Financ., 2020.

[20]Bappenas RI, "Perkembangan Ekonomi Indonesia dan Dunia: Ancaman Resesi Dunia Akibat Pandemi," Jakarta, 2020.

[21]H. Saraswati, "Dampak Pandemi Covid-19 Terhadap 
Pasar Saham Di Indonesia," JAD J. Ris. Akunt. dan Keuang. Dewantara, vol. 3, no. 2, 2020.

[22] M. Utami and M. Rahayu, "Peranan Profitabilitas, Suku Bunga, Inflasi dan Nilai Tukar Dalam Mempengaruhi Pasar Modal Indonesia Selama Krisis Ekonomi," J. Manaj. dan Kewirausahaan, vol. 5, no. 2, pp. 123-131, 2003. 